\title{
The Research of the V-I Characteristics of a Solar Panel Using a Computerized Measuring Bench "EPH 2 Advanced Photovoltaics Trainer"
}

\author{
Mirzayev Uchqun, Tulakov Jahongir \\ Department of Electric Power Industry, Faculty of Electromechanics and Radioelectronics, Jizzakh Polytecnic Institute, Jizzakh, Uzbekistan \\ Email address: \\ goodluck_0714@mail.ru(T. Jahongir)

\section{To cite this article:} \\ Mirzayev Uchqun, Tulakov Jahongir. The Research of the V-I Characteristics of a Solar Panel Using a Computerized Measuring Bench \\ “EPH 2 Advanced Photovoltaics Trainer". Automation, Control and Intelligent Systems. Vol. 7, No. 3, 2019, pp. 79-83. \\ doi: $10.11648 /$ j.acis.20190703.11
}

Received: February 19, 2019; Accepted: March 28, 2019; Published: August 16, 2019

\begin{abstract}
At present, much attention is paid to the use of solar energy. Solar energy, in addition to traditional energy, is ecologically clean while changing. The rarity and the rising cost of fuel is one of the main problems of the scientific technique, which is the acquisition of infinite resources of solar energy. Further research and experiments on the use of solar energy, as well as the use of solar power plants in a number of countries, shows that solar energy can be widely used today based on modern technical capacities. In order to determine the need to use a charger, it is necessary to know a number of parameters: short circuit current, no-load voltage, efficiency, etc. In this work, these parameters are estimated from the results of studies of the current-voltage characteristic of a solar panel obtained in automatic mode using a computer and digital measuring device "EPH 2 Advanced photovoltaics trainer".
\end{abstract}

Keywords: Solar Cell, Solar Panel, Solar Battery, Current Source, Charger, Volt-Ampere Characteristic, Coefficient of Performance, Radiation Meter

\section{Introduction}

At present, much attention is paid to the use of solar energy. Solar energy, in addition to traditional energy, is ecologically clean while changing. The rarity and the rising cost of fuel is one of the main problems of the scientific technique, which is the acquisition of infinite resources of solar energy. Further research and experiments on the use of solar energy, as well as the use of solar power plants in a number of countries, shows that solar energy can be widely used today based on modern technical capacities. Air air pollution can be monitored by numerous interactions with toxic gasses, dust particles, in addition to oxygen, ozone, nitrogen, carbon dioxide gas and other air. One of the main factors that keep the fresh air is the toxic gases emitted by motor vehicles. The carbon dioxide gas is heavier than the air, and it is always concentrated near the Earth's surface. The harmful side of the gas is that it joins the hemoglobin in the blood and prevents oxygen from reaching the body cells.
Also, acrolein, formaldehyde, tetraethyl lead in car gas also negatively affects human health. In addition, one of the areas that polluting the air is heat cogeneration, thermal power plants and boiler installations. The amount of toxic substances emitted from heat exchangers is very large. For example, an electric boiler station that consumes 51,000 tons of coal per day produces 33 tons of sulfur dioxide into the air. Given the fact that it is 50 tons of sulfuric acid in favorable meteorological conditions, 40-50 tons of lime is removed every day.

\section{Materials and Methods}

PV cells can be modeled as a current source in parallel with a diode. When there is no light present to generate any current, the PV cell behaves like a diode. As the intensity of incident light increases, current is generated by the PV cell, as illustrated in Figure 1. 

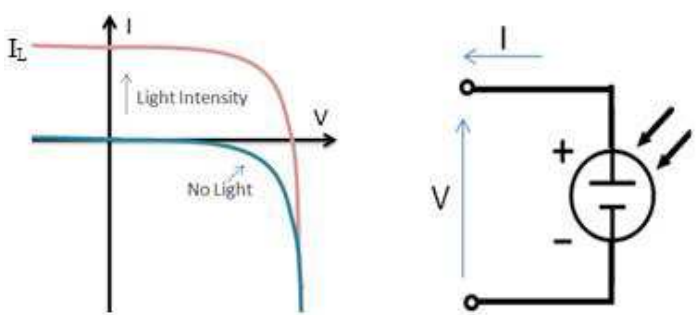

Figure 1. I-V Curve of PV Cell and Associated Electrical Diagram.

In an ideal cell, the total current $\mathrm{I}$ is equal to the current $\mathrm{I}_{\ell}$ generated by the photoelectric effect minus the diode current $\mathrm{I}_{\mathrm{D}}$, according to the equation:

$$
I=I_{l}-I_{D}=I_{l}-I_{0}\left(\mathrm{e}^{\frac{q V}{k T}}-1\right)
$$

where $I_{0}$ is the saturation current of the diode, $q$ is the elementary charge $1.6 \times 10^{-19}$ Coulombs, $\mathrm{k}$ is a constant of value $1.38 \times 10^{-23} \mathrm{~J} / \mathrm{K}, \mathrm{T}$ is the cell temperature in Kelvin, and $\mathrm{V}$ is the measured cell voltage that is either produced (power quadrant) or applied (voltage bias). A more accurate model will include two diode terms, however, we will concentrate on a single diode model in this document [1-2].

Expanding the equation gives the simplified circuit model shown below and the following associated equation, where $n$ is the diode ideality factor (typically between 1 and 2), and $\mathrm{R}_{\mathrm{S}}$ and $\mathrm{R}_{\mathrm{SH}}$ represents the series and shunt resistances that are described in further detail later in this document:

$$
I=I_{l}-I_{0}\left(\mathrm{e}^{\frac{q\left(Y+I R_{s}\right)}{n l T}}-1\right)-\frac{V+I R_{s}}{R_{s h}}
$$

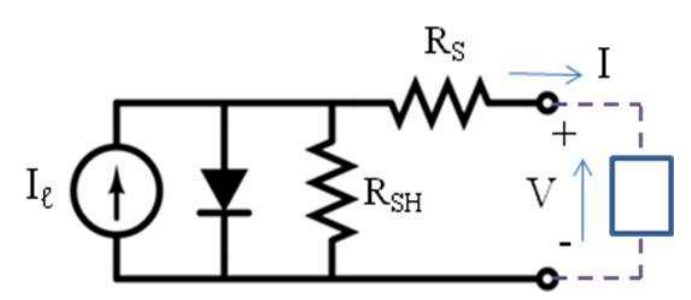

Figure 2. Simplified Equivalent Circuit Model for a Photovoltaic Cell.

The I-V curve of an illuminated PV cell has the shape shown in Figure 3 as the voltage across the measuring load is swept from zero to $\mathrm{V}_{\mathrm{OC}}$, and many performance parameters for the cell can be determined from this data, as described in the sections below.

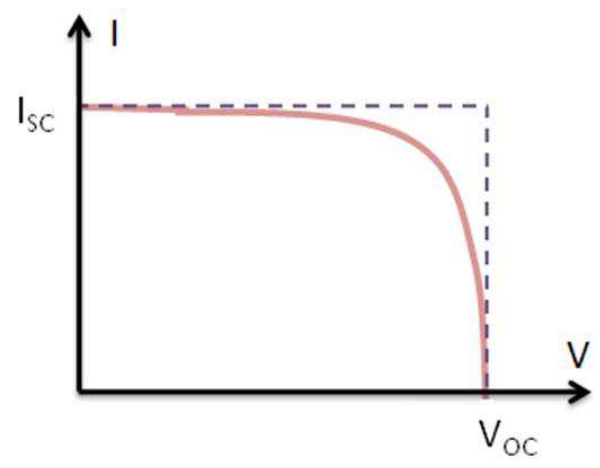

Figure 3. Illuminated I-V Sweep Curve.
Short Circuit Current $\left(\mathrm{I}_{\mathrm{SC}}\right)$

The short circuit current $\mathrm{I}_{\mathrm{SC}}$ corresponds to the short circuit condition when the impedance is low and is calculated when the voltage equals 0 .

$$
\mathrm{I}(\text { at } \mathrm{V}=0)=\mathrm{I}_{\mathrm{SC}}
$$

$\mathrm{I}_{\mathrm{SC}}$ occurs at the beginning of the forward-bias sweep and is the maximum current value in the power quadrant. For an ideal cell, this maximum current value is the total current produced in the solar cell by photon excitation [3-4].

$\mathrm{I}_{\mathrm{SC}}=\mathrm{I}_{\mathrm{MAX}}=\mathrm{I}_{\ell}$ for forward-bias power quadrant

Open Circuit Voltage $\left(\mathrm{V}_{\mathrm{OC}}\right)$

The open circuit voltage $\left(\mathrm{V}_{\mathrm{OC}}\right)$ occurs when there is no current passing through the cell.

$$
\mathrm{V}(\text { at } \mathrm{I}=0)=\mathrm{V}_{\mathrm{OC}}
$$

$\mathrm{V}_{\mathrm{OC}}$ is also the maximum voltage difference across the cell for a forward-bias sweep in the power quadrant [15].

$\mathrm{V}_{\mathrm{OC}}=\mathrm{V}_{\mathrm{MAX}}$ for forward-bias power quadrant

Maximum Power $\left(\mathrm{P}_{\mathrm{MAX}}\right)$, Current at $\mathrm{P}_{\mathrm{MAX}}\left(\mathrm{I}_{\mathrm{MP}}\right)$, Voltage at $\mathrm{P}_{\text {MAX }}\left(\mathrm{V}_{\mathrm{MP}}\right)$

\section{Result}

The power produced by the cell in Watts can be easily calculated along the I-V sweep by the equation $\mathrm{P}=\mathrm{IV}$. At the $\mathrm{I}_{\mathrm{SC}}$ and $\mathrm{V}_{\mathrm{OC}}$ points, the power will be zero and the maximum value for power will occur between the two [13-14]. The voltage and current at this maximum power point are denoted as $\mathrm{V}_{\mathrm{MP}}$ and $\mathrm{I}_{\mathrm{MP}}$ respectively [5-6].

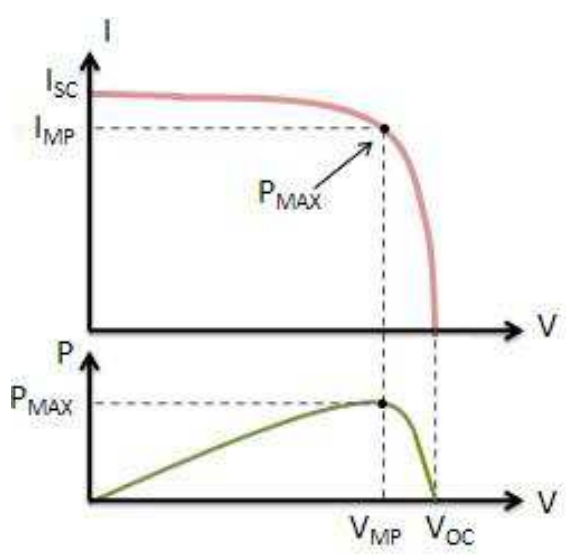

Figure 4. Maximum Power for an I-V Sweep.

Fill Factor (FF)

The Fill Factor (FF) is essentially a measure of quality of the solar cell. It is calculated by comparing the maximum power to the theoretical power $\left(\mathrm{P}_{\mathrm{T}}\right)$ that would be output at both the open circuit voltage and short circuit current together. FF can also be interpreted graphically as the ratio of the rectangular areas depicted in Figure 5.

$$
F F=\frac{P_{M A X}}{P_{T}}=\frac{I_{M P} V_{M P}}{I_{S C} V_{O C}}
$$



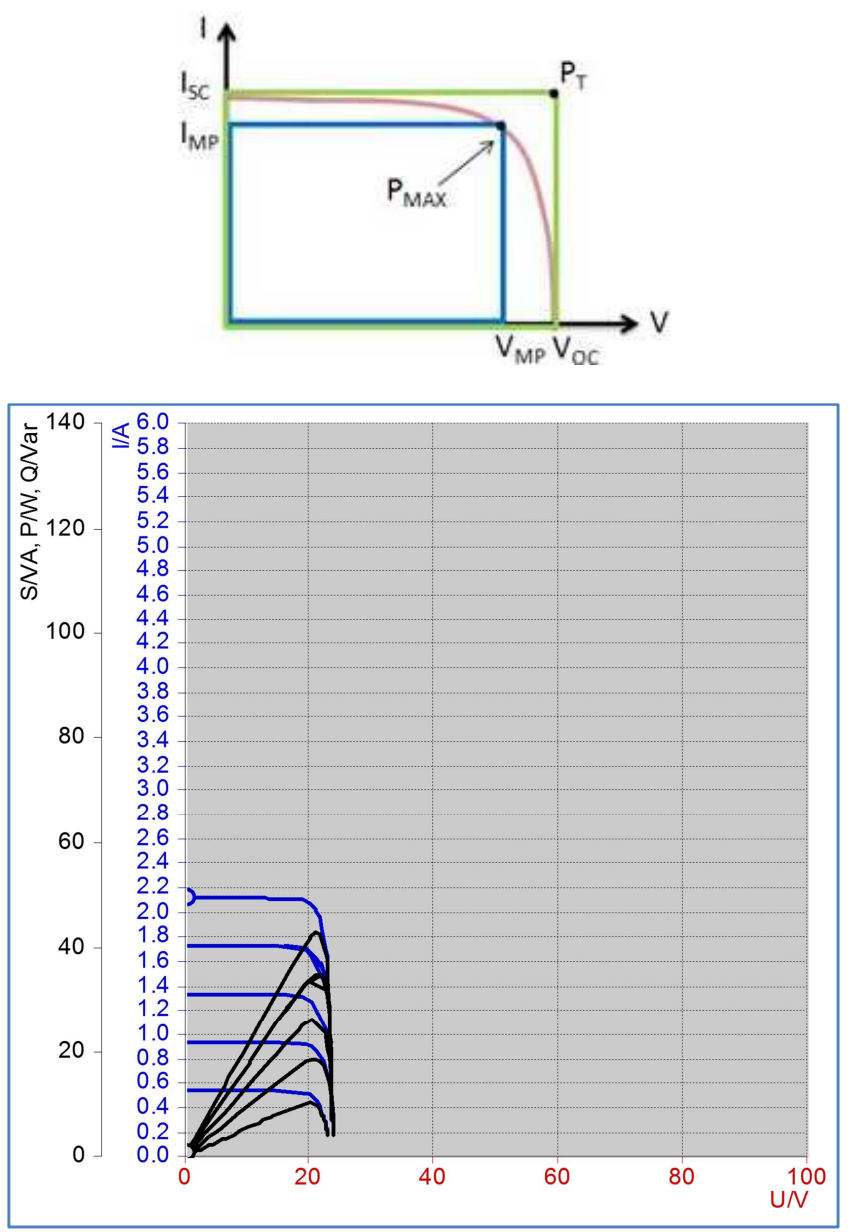

Figure 5. Getting the Fill Factor From the I-V Sweep was taken "EPH 2 Advanced photovoltaics trainer".

A larger fill factor is desirable, and corresponds to an I-V sweep that is more square-like. Typical fill factors range from 0.5 to 0.82 . Fill factor is also often represented as a percentage.

Efficiency $(\eta)$

Efficiency is the ratio of the electrical power output $\mathrm{P}_{\text {out }}$, compared to the solar power input, $\mathrm{P}_{\text {in }}$, into the PV cell. $\mathrm{P}_{\text {out }}$ can be taken to be $\mathrm{P}_{\mathrm{MAX}}$ since the solar cell can be operated up to its maximum power output to get the maximum efficiency.

$$
\eta=\frac{P_{\text {out }}}{P_{\text {in }}} \quad \Rightarrow \quad \eta=\frac{P_{M A X}}{P_{\text {in }}}
$$

$\mathrm{P}_{\text {in }}$ is taken as the product of the irradiance of the incident light, measured in $\mathrm{W} / \mathrm{m}^{2}$ or in suns $\left(1000 \mathrm{~W} / \mathrm{m}^{2}\right)$, with the surface area of the solar cell $\left[\mathrm{m}^{2}\right]$. The maximum efficiency $\left(\eta_{\text {MAX }}\right)$ found from a light test is not only an indication of the performance of the device under test, but, like all of the I-V parameters, can also be affected by ambient conditions such as temperature and the intensity and spectrum of the incident light [11-12]. For this reason, it is recommended to test and compare PV cells using similar lighting and temperature conditions. These standard test conditions are discussed in Part III.

\section{Discussion}

Shunt Resistance $\left(\mathrm{R}_{\mathrm{SH}}\right)$ and Series Resistance $\left(\mathrm{R}_{\mathrm{S}}\right)$

During operation, the efficiency of solar cells is reduced by the dissipation of power across internal resistances. These parasitic resistances can be modeled as a parallel shunt resistance $\left(R_{S H}\right)$ and series resistance $\left(R_{S}\right)$, as depicted in Figure 2.

For an ideal cell, $\mathrm{R}_{\mathrm{SH}}$ would be infinite and would not provide an alternate path for current to flow, while $\mathrm{R}_{\mathrm{S}}$ would be zero, resulting in no further voltage drop before the load [7-8].

Decreasing $\mathrm{R}_{\mathrm{SH}}$ and increasing $\mathrm{R}_{\mathrm{s}}$ will decrease the fill factor (FF) and $\mathrm{P}_{\mathrm{MAX}}$ as shown in Figure 6. If $\mathrm{R}_{\mathrm{SH}}$ is decreased too much, $V_{O C}$ will drop, while increasing $R_{S}$ excessively can cause $\mathrm{I}_{\mathrm{SC}}$ to drop instead.

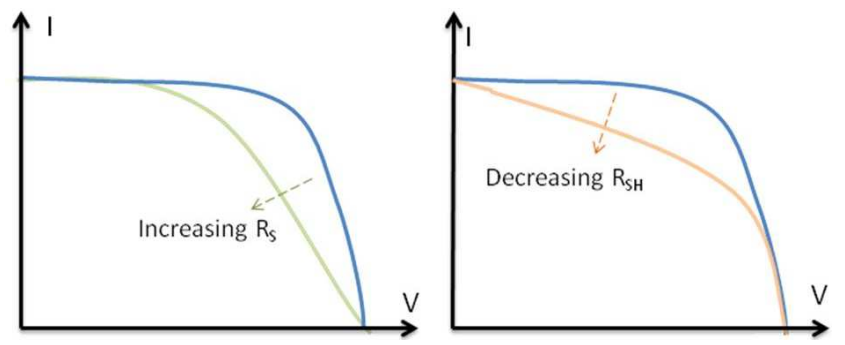

Figure 6. Effect of Diverging $R_{s} \& R_{S H}$ From Ideality.

It is possible to approximate the series and shunt resistances, $R_{S}$ and $R_{S H}$, from the slopes of the I-V curve at $\mathrm{V}_{\mathrm{OC}}$ and $\mathrm{I}_{\mathrm{SC}}$, respectively. The resistance at Voc, however, is at best proportional to the series resistance but it is larger than the series resistance. $\mathrm{R}_{\mathrm{SH}}$ is represented by the slope at $\mathrm{I}_{\mathrm{SC}}$. Typically, the resistances at $\mathrm{I}_{\mathrm{SC}}$ and at $\mathrm{V}_{\mathrm{OC}}$ will be measured and noted, as shown in Figure 7.

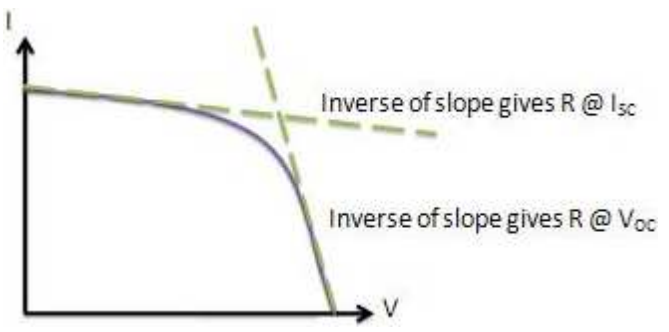

Figure 7. Obtaining Resistances from the I-V Curve.

If incident light is prevented from exciting the solar cell, the I-V curve shown in Figure 8 can be obtained. This I-V curve is simply a reflection of the "No Light" curve from Figure 1 about the $\mathrm{V}$-axis. The slope of the linear region of the curve in the third quadrant (reverse-bias) is a continuation of the linear region in the first quadrant, which is the same linear region used to calculate $\mathrm{R}_{\mathrm{SH}}$ in Figure 7. It follows that $\mathrm{R}_{\mathrm{SH}}$ can be derived from the I-V plot obtained with or without providing light excitation, even when power is sourced to the cell. It is important to note, however, that for real cells, these resistances are often a function of the light level, and can differ in value between the light and dark tests [9-10]. 


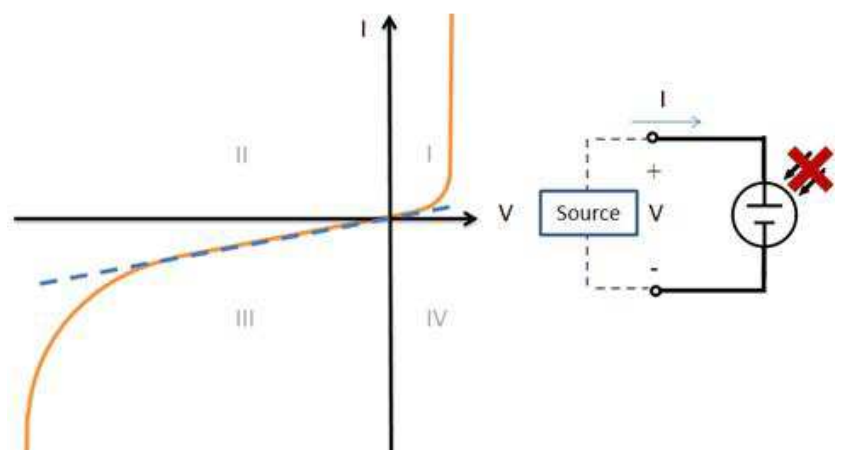

Figure 8. I-V Curve of Solar Cell Without Light Excitation.

Temperature Measurement Considerations

The crystals used to make PV cells, like all semiconductors, are sensitive to temperature. Figure 9 depicts the effect of temperature on an I-V curve. When a PV cell is exposed to higher temperatures, $\mathrm{I}_{\mathrm{SC}}$ increases slightly, while $\mathrm{V}_{\mathrm{OC}}$ decreases more significantly.

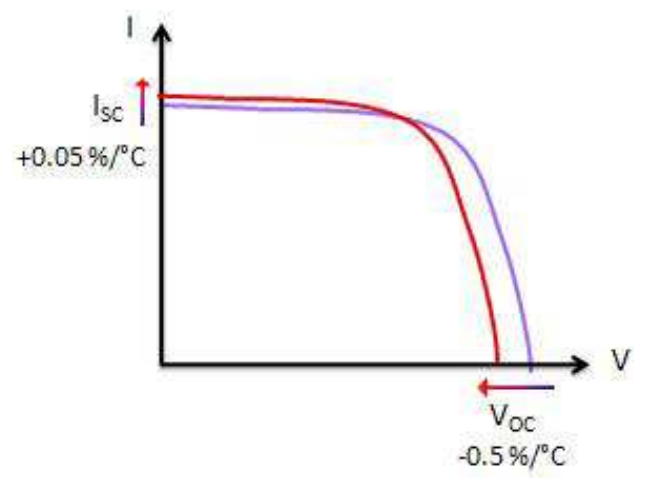

Figure 9. Temperature Effect on I-V Curve.

For a specified set of ambient conditions, higher temperatures result in a decrease in the maximum power output $\mathrm{P}_{\mathrm{MAX}}$. Since the $\mathrm{I}-\mathrm{V}$ curve will vary according to temperature, it is beneficial to record the conditions under which the I-V sweep was conducted. Temperature can be measured using sensors such as RTDs, thermistors or thermocouples.

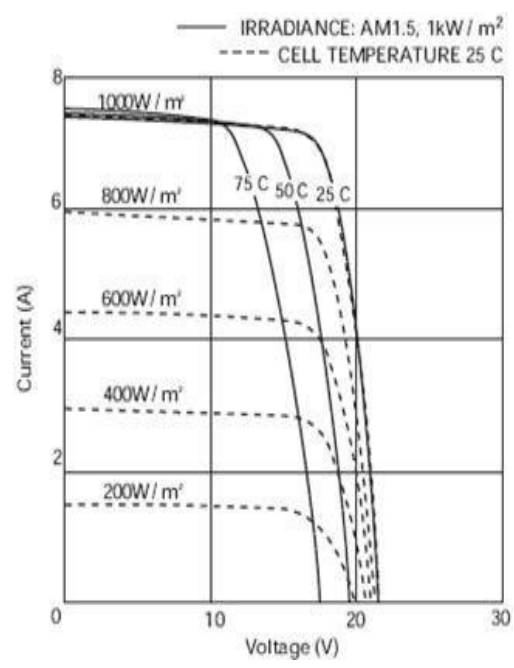

Figure 10. Temperature Effect on I-V Curve.
I-V Curves for Modules

For a module or array of PV cells, the shape of the I-V curve does not change. However, it is scaled based on the number of cells connected in series and in parallel. When $n$ is the number of cells connected in series and $\mathrm{m}$ is the number of cells connected in parallel and $\mathrm{I}_{\mathrm{SC}}$ and $\mathrm{V}_{\mathrm{OC}}$ are values for individual cells, the I-V curve shown in Figure 10 is produced.

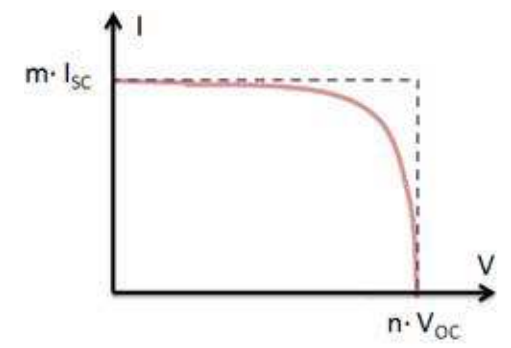

Figure 11. I-V Curve for Modules and Arrays.

\section{Conclusions}

The maximum power produced decreases by about $30 \%$ when solar irradiance decreases from $1,000 \mathrm{~W} / \mathrm{m}^{2}$ to 700 $\mathrm{W} / \mathrm{m}^{2}$ level and further lowers by about $31 \%$ when solar irradiance decreases from $700 \mathrm{~W} / \mathrm{m}^{2}$ to $400 \mathrm{~W} / \mathrm{m}^{2}$ level. The effect of operating temperature is also studied on the Pmp, which shows that at the same irradiance of $1,000 \mathrm{~W} / \mathrm{m}^{2}$, Pmpdecreases by about $14 \%$ when the cell operation temperature is lowered from $100^{\circ} \mathrm{C}$ to $50^{\circ} \mathrm{C}$. The developed model can accurately predict the per-formance of the PV solar panels.

\section{References}

[1] Sergio Daher, Jurgen Schmid and Fernando L. M Antunes, "Multilevel Inverter Topologies for Stand-Alone PV Systems" IEEE Transactions on Industrial Electronics. Vol. 55, No. 7, July 2008.

[2] J. Surya Kumari and Ch. Sai Babu "Mathematical Modeling and Simulation of Photovoltaic Cell using Matlab-Simulink Environment" International Journal of Electrical and Computer Engineering (IJECE) Vol. 2, No. 1, February 2012, pp. 26 34 ISSN: 2088-8708.

[3] J. A. Gow and C. D. Manning, Development of a photovoltaic array model for use in power-electronics simulation studies, IEE Proceedings - Electric Power Applications, 146 (1999), 193-200.

[4] E. I. Ortiz-Rivera and F. Z. Peng, Analytical model for a photovoltaic module using the electrical characteristics provided by the manufacturer data sheet, in 36th IEEE Power Electronics Specialists Conference (PESC '05), Recife, Brazil, 2005, 2087-2091.

[5] V. P. Sethi, K. Sumathy, S. Yuvarajan, and D. S. Pal "Mathematical Model for Computing Maximum Power Output of a PV Solar Module and Experimental Validation" Ashdin Publishing Journal of Fundamentals of Renewable Energy and Applications Vol. 2 (2012), Article ID R120312, 5pages doi: 10.4303/jfrea/R120312. 
[6] Hiren Patel and Vivek Agarwal, "MATLAB-Based Modeling to Study the Effects of Partial Shading on PV Array Characteristics", IEEE TRANSACTIONS ON ENERGY CONVERSION, VOL 23, NO 1, MARCH 2008.

[7] Byers T. 20 designs with solar cells. M. Mir, 1988.

[8] Bayramov R. Toiliev KT, Ashirbaev M. Thermal regime of a solar house with passive thermoelements. Izv. AN RTADJ. Ser. FTH and GN. 1981. №1.

[9] Vasiliev D. V., Filippov G. S. Fundamentals of the theory and calculation of tracking systems. M: JL: Gosenergoizdat, 1959.

[10] Garf B. A. The mechanism of rotation of mobile solar installations // Use of solar energy. Issue 1. M.: Publishing House of the Academy of Sciences, 1957. S. 62-84.
[11] Duffy J. A., Beckman W. A. Thermal processes using solar energy. M.: Mir, 1977.

[12] Dynamics and energy characteristics of servo drives of intermittent control. / Ed. Kistika S. V. Works MAI. Issue 217. M., 1971.

[13] Zhimerin D. G. Energy present and future. M.: Knowledge, 1978.-189 p.

[14] Zahidov R. A. Technology and testing of solar concentrating systems. Tashkent. FAN, 1978.

[15] Ivakhnenko A. G. Connection of the theory of invariance with the theory of differential regulators. /Automation. 1961. №1. 